\title{
Exploring the basis of thermotolerance in the reef coral Goniastrea aspera
}

\author{
B. E. Brown ${ }^{1, *}$, C. A. Downs ${ }^{2}$, R. P. Dunne ${ }^{1}$, S. W. Gibb ${ }^{3}$ \\ ${ }^{1}$ Department of Marine Sciences and Coastal Management, University of Newcastle, Newcastle upon Tyne NE1 7RU, \\ United Kingdom \\ ${ }^{2}$ EnVirtue Biotechnologies Inc, 2255 Ygnacio Valley Road, Suite H-1 Walnut Creek, California 94598, USA \\ ${ }^{3}$ Environmental Research Institute, The North Highland College, UHI Millennium Institute, Castle Street, Thurso, \\ Caithness KW14 7JD, Scotland, United Kingdom
}

\begin{abstract}
The shallow-water reef coral Goniastrea aspera Verill 1865 has previously been reported to demonstrate differences in within-colony susceptibility to bleaching at elevated sea temperatures; parts of the colony which are exposed to the highest solar radiation are more thermotolerant than areas which are less exposed. In this paper, we show that at elevated experimental sea temperature the 'high light' surfaces lose fewer symbiotic algae, have lower levels of oxidative stress, higher levels of host antioxidant-enzyme copper zinc superoxidase dismutase (CuZnSOD), and host heat-shock proteins 60 and 70, compared to the less exposed surfaces. In addition, 'high light' surfaces show less chronic photoinhibition and greater Photosystem II (PS II) recovery potential when exposed to high irradiance at ambient sea temperature. In contrast, no differences were noted in algal defences (e.g. antioxidant enzymes and stress protein production, and xanthophyll cycling) either at elevated or ambient temperatures. These results are noteworthy because they suggest that corals which acclimatise to high irradiance can, as a result, develop increased thermotolerance which may prevent bleaching at high sea temperatures. Importantly, they also demonstrate the significance of the host tissues in maintaining the intact symbiosis of $G$. aspera under thermal stress.
\end{abstract}

KEY WORDS: Corals · Thermotolerance $\cdot$ Acclimatisation · Irradiance stress

Resale or republication not permitted without written consent of the publisher

\section{INTRODUCTION}

There has been considerable discussion in the recent literature about the scope of corals to acclimatise to climate-induced elevations in sea temperature (Buddemeier \& Fautin 1993, Brown 1997, Ware 1997, Buddemeier \& Smith 1999, Gates \& Edmunds 1999, HoeghGuldberg 1999). Most attention to date has focussed on the symbiotic algae, rather than on the coral host, as agents which might confer increased tolerance against the potentially damaging interaction of elevated temperature and irradiance anticipated to affect coral reefs in future years (Fitt et al. 2001). Such studies

*E-mail: 101515.1267@compuserve.com include testing the hypothesis that altered environmental conditions might favour the exchange of algal symbionts in the coral host to those which are better adapted to more stressful environments (Buddemeier \& Fautin 1993, Rowan et al. 1997, Baker 2001, HoeghGuldberg et al. 2002) and investigations which highlight the physiological plasticity vested in algal defence mechanisms against elevated temperature/ irradiance such as antioxidant enzymes (Lesser \& Shick 1989, Lesser at al 1990, Lesser 1997); downregulation of photosynthesis (Brown et al. 1999a, Hoegh-Guldberg \& Jones 1999) and xanthophyll cycling (Ambarsari et al. 1997, Brown et al. 1999a,b). Although host responses have not been ignored, their study has been more limited, being restricted to photoprotective defences such as sunscreen compounds 
(Shick et al. 1996) and fluorescent pigments (Salih et al. 2000, Dove et al. 2001) which restrict penetration of light into coral tissues, and heat-shock protein (hsp) production (Black et al. 1995, Sharp et al. 1997, Gates \& Edmunds 1999, Downs et al. 2000) which limits damage to cellular function during environmental stress.

Studies that have demonstrated the acclimation/ acclimatisation of corals to elevated temperature are limited. Early experiments showed that subtropical corals had an upper lethal limit that was $2^{\circ} \mathrm{C}$ lower than their tropical counterparts, while Hawaiian corals that survived $56 \mathrm{~d}$ exposures to temperatures of 1 to $2^{\circ} \mathrm{C}$ above seasonal maxima had higher survival rates than ambient controls when exposed to temperatures of 30 to $32.5^{\circ} \mathrm{C}$ for $5 \mathrm{~d}$ (Coles et al. 1976, Coles \& Jokiel 1978). Berkelmans \& Willis (1999) reported a $1^{\circ} \mathrm{C}$ difference in the temperature at which Pocillopora damicornis from the Great Barrier Reef bleached in winter and summer temperature tolerance experiments, but the lack of proximate solar radiation data is a serious weakness. While corals have been found in extreme temperature environments that range from tidal pools, where sea temperatures exceed $34^{\circ} \mathrm{C}$ on a regular basis (Gardiner 1903, Orr \& Moorhouse 1933, Craig et al. 2001), to thermal vents in Indonesia where sea temperatures range from 34 to $37^{\circ} \mathrm{C}$ (Tomascik et al. 1997), quantitative evidence for acclimatisation and the timescales involved remains scant.

Recent work on the bleaching patterns exhibited by the reef coral Goniastrea aspera, during exposure to elevated sea temperatures in the field, may offer some insights into acclimatory processes of corals (Brown et al. 2000a). This species is abundant in shallow reef-flat settings throughout the Indo-Pacific. During periods of elevated sea temperature in 1991, 1995 and 1998 on fringing reefs around the south east tip of Phuket, Thailand, in the eastern Indian Ocean, it was noted that many colonies of $G$. aspera bleached preferentially on their eastern sides. This was remarkable because earlier in the year bleached areas were confined to the west sides of colonies which received higher irradiance than more shaded east sides during afternoon aerial exposure on low spring tides; a phenomenon which has been termed 'solar bleaching' (Brown et al. 1994). Subsequent experimental work showed that west sides of corals have a significantly higher temperature tolerance than east sides (Brown et al. 2000a). These differential bleaching responses on either side of the colony cannot be attributed to genetic differences in symbiotic algae, as demonstrated in other corals (Rowan et al. 1997), but are very likely due to the prior experience of western surfaces to elevated irradiance throughout the year (Brown et al. 2002a). This example of within-colony variation in temperature responses of coral colonies provides a very useful model for the investigation of physiological mechanisms involved in acclimatisation and also the nature of the co-tolerance developed to irradiance and temperature. In the present study, a range of molecular biomarkers were investigated in east and west sides of corals exposed to elevated sea temperatures, alongside measures of symbiotic algal density and photosynthetic efficiency of algal symbionts. Molecular biomarkers included indicators of oxidative stress in the total symbiosis, together with antioxidant enzyme and heat shock protein concentrations in both coral host and algae. Earlier work has shown that oxidative stress is central to the bleaching response (Lesser 1997) and therefore. antioxidative enzyme production and activity are likely to be important defences in thermotolerant corals. Many of the biomarkers used in the present study had already proved to be successful indicators of stress in corals exposed to elevated sea temperatures in the laboratory (Downs et al. 2000).

\section{MATERIALS AND METHODS}

Collection and maintenance of corals. In February 2001, 142 coral cores were collected from differently orientated faces of Goniastrea aspera in the manner described in earlier papers (Le Tissier \& Brown 1996, Ambarsari et al. 1997, Brown et al. 1999a). A pair of cores (25 mm diam) was drilled from 66 colonies, one from the east and one from the west face, for experimental work. In addition, 2 cores were drilled from each east and west face of 5 colonies to provide baseline samples for molecular and pigment analyses. All cores were collected on an evening tide and those required for experimental work were immediately returned to the laboratory in shaded containers within 30 min of collection. These cores were then divided equally between 2 shallow experimental aquaria supplied with running seawater and exposed to ambient solar radiation. Both aquaria were maintained at ambient sea temperatures $\left(29.4 \pm 0.5^{\circ} \mathrm{C}\right.$, range 28.7 to $31.1^{\circ} \mathrm{C}$ ). The cores were covered by $10 \mathrm{~cm}$ of seawater which flowed over the corals at a rate of 3 to $41 \mathrm{~min}^{-1}$. Corals were acclimated to laboratory conditions overnight before the start of the experiment the following morning, when sea temperature in one of the tanks was raised to $33.6^{\circ} \mathrm{C}\left( \pm 0.25^{\circ} \mathrm{C}\right.$, range 33.1 to $\left.35.2^{\circ} \mathrm{C}\right)$. Samples collected for baseline analyses were placed on ice in the field and then on return to the laboratory were immediately transferred to $\mathrm{a}-50^{\circ} \mathrm{C}$ freezer before preparation for analysis.

Two matched PAR $2 \pi$ cosine corrected quantum sensors (Macam Photometrics SD101QV-Cos) were used to record above and below downwelling irradiance at $1 \mathrm{~min}$ intervals in the experimental aquaria. Both 
sensors were calibrated as described in Brown et al. (1999). Seawater temperature was recorded with logging thermistors (Seamon Mini absolute accuracy $\pm 0.05^{\circ} \mathrm{C}$ ) every $5 \mathrm{~min}$.

Sampling strategy. The experiment was conducted over a 4 d period in February 2001. Baseline cores (5 east and 5 west), collected before the experiment began, were sacrificed for molecular and pigment analyses and also for measurement of zooxanthellae densities. Algal photophysiology was monitored, using chlorophyll (chl a) fluorescence, every $2 \mathrm{~h}$ from well before dawn (06:50 h) under conditions of total darkness to $21.00 \mathrm{~h}$ daily, throughout the experiment using between 7 and 14 cores from east and west faces of coral colonies from both elevated and ambient sea water tanks. Twenty cores from these tanks were also sampled for molecular ( 5 east and 5 west) and pigment (5 east and 5 west) analyses at 12:30 h on the Days 1 and 2 of the experiment. In addition, 5 east and 5 west cores were sacrificed for measurement of zooxanthellae densities at the conclusion of the experiment from ambient and elevated temperature tanks.

It might be argued that our experimental design involved pseudoreplication since all the samples were held in just 2 separate treatment tanks. However, the difficulties in maintaining identical experimental conditions for replicate samples in separate containers is virtually insurmountable. We consider that our regime which involved small coral biomass, large tank volumes and a high water flow of 3 to $41 \mathrm{~min}^{-1}$ minimised any effects of pseudoreplication, whilst benefiting from truly identical conditions.

Molecular assays. Coral cores were stored at $-50^{\circ} \mathrm{C}$ until analysis, approximately $48 \mathrm{~h}$ after collection. Tissue samples were scraped from the coral skeleton and ground to a powder using a liquid nitrogen chilled ceramic pestle and mortar. Samples ( 100 mg) of wet tissue were placed in $1.8 \mathrm{ml}$ microcentrifuge tubes and $600 \mu \mathrm{l}$ of a denaturing buffer consisting of $2 \%$ SDS, $50 \mathrm{mM}$ Tris- $\mathrm{HCl}$ (pH 6.8), $75 \mathrm{mM}$ dithiothreitol, $10 \mathrm{mM}$ EDTA, $0.01 \mathrm{mM}$ sorbitol, $7 \%$ polyvinylpolypyrrolidone $(\mathrm{w} / \mathrm{v}), 1 \%$ polyvinylpyrrolidone (w/v), $0.1 \mathrm{mM}$ alphatocopherol, $0.005 \mathrm{mM}$ salicylic acid, $0.01 \mathrm{mM}$ AEBSF, $0.04 \mathrm{mM}$ Bestatin, $0.001 \mathrm{mM}$ E-64, $2 \mathrm{mM}$ phenyl methylsulfonyl fluoride, $2 \mathrm{mM}$ benzamide, $5 \mathrm{mM}$ aamino-caproic acid and $0.1 \mathrm{mg} \mathrm{ml}^{-1}$ pepstatin A. Samples were boiled for $3 \mathrm{~min}$, vortexed for $20 \mathrm{~s}$, boiled for another $3 \mathrm{~min}$, and then incubated at $25^{\circ} \mathrm{C}$ for $5 \mathrm{~min}$. Samples were then centrifuged at $10000 \times g$ for $5 \mathrm{~min}$. Supernatant, minus any lipid/glycoprotein mucilage matrix, was transferred to a new tube, centrifuged at $10000 \times g$ for $5 \mathrm{~min}$ and supernatent minus lipid/glycoprotein mucilage matrix was transferred to a new tube and subjected to protein concentration assay by the method of Ghosh et al. (1988).
Quality control of sample preparation for ELISA analysis was determined by subjecting 4 random samples to 2 different protocols. One protocol subjected samples to SDS-PAGE ( 7 and $12.5 \%$ G250). A second protocol subjected samples to SDS-PAGE (12.5\% polyacrylamide gel) with gels stained with coomassie blue (brilliant blue G250). A second protocol subjected samples to SDS-PAGE (12.5\% polyacrylamide gel), Western plotting onto PVDF membrane, and the membrane assayed with each of the antibodies used in this study to ensure specific cross-reactivity, and absence of nonspecific cross-reactivity and mucilage product artefact. Samples were then assayed by ELISA as described in Downs et al. (2000). Samples were assayed for the end products of oxidative stress namely, 4-Hydroxynonenal (HNE) and malondialdehyde (MDA); ubiquitin which is a marker of protein degradation; the heat shock proteins (scleractinian and algal Hsp60 and Hsp70); chloroplast small heat shock protein (ChlsHsp); and the antioxidant enzymes copper zinc superoxidase dismutase (scleractinian and algal CuZnSOD) and manganese superoxide dismutase (scleractinian and algal MnSOD). The biological significance of the majority of markers selected in this study is summarised in Table 1 and described in detail in Downs et al. (2000). The biomarkers HNE, MDA and ubiquitin were measured in the whole symbiosis; ChlsHsp in the symbiotic algae and the Hsps and antioxidant enzymes in both host and algal fractions.

All samples were analysed in triplicate. Once developed, blots were scanned and analysed using National Institute of Health image software. A serial dilution of purified protein for each parameter was included in each assay to allow sample quantification and assay quality control. Concentration standards for each assay were determined and a quadratic or polynomial equation used to determine the concentration of each sample.

Measurement of algal pigment concentrations. On collection, all cores were placed in the freezer at $-50^{\circ} \mathrm{C}$. Subsequently, tissue was removed from the cores by air gunning and prepared for analysis as described by Ambarsari et al. (1997). Resulting pellets were then stored in liquid nitrogen for transportation. The pellets were homogenised in $10 \mathrm{mN}$ Tris- $\mathrm{HCl}$ buffer and a sub-sample removed for measurement of algal numbers, so that pigment concentrations could be computed per algal cell. The remaining cells were centrifuged for $5 \mathrm{~min}$ at $1800 \times g$ and the resulting pellets extracted in methanol for analysis by reversephase high performance liquid chromatography. Pigments were analysed using a modified version of Barlow et al. (1998). Analyses were performed using an integrated PC-interfaced Thermo-Separations HPLC system comprising vacuum degasser (SCM 1000), qua- 
Table 1. Biological significance of the molecular assays selected in the present study

\begin{tabular}{|c|c|}
\hline Molecular assay & Biological significance \\
\hline \multicolumn{2}{|l|}{ Whole symbiosis } \\
\hline $\begin{array}{l}\text { HNE } \\
\text { MDA }\end{array}$ & $\begin{array}{l}\text { Products of lipid peroxidation and } \\
\text { indicators of oxidative damage }\end{array}$ \\
\hline Ubiquitin & $\begin{array}{l}\text { Involved in marking proteins for rapid } \\
\text { degradation and an indicator of cellular } \\
\text { damage }\end{array}$ \\
\hline \multicolumn{2}{|l|}{ Animal host } \\
\hline $\begin{array}{l}\text { CuZnSOD } \\
\text { MnSOD }\end{array}$ & $\begin{array}{l}\text { Important enzymes involved in the anti- } \\
\text { oxidant defence pathway. Any increase } \\
\text { in the concentration and activity of these } \\
\text { enzymes would suggest a defence re- } \\
\text { sponse by the animal host in response to } \\
\text { oxidative stress }\end{array}$ \\
\hline Hsp 60 and 70 & $\begin{array}{l}\text { Molecular chaperones which regulate } \\
\text { protein structure, particularly following } \\
\text { stress when they are involved in recon- } \\
\text { stituting denatured proteins. Any in- } \\
\text { crease in concentration of Hsps would } \\
\text { suggest a defence response by the animal } \\
\text { host in response to stress }\end{array}$ \\
\hline \multicolumn{2}{|l|}{ Symbiotic alga } \\
\hline $\begin{array}{l}\text { CuZnSOD } \\
\text { MnSOD }\end{array}$ & $\begin{array}{l}\text { Function as outlined above but increases } \\
\text { in concentration and activity indicating a } \\
\text { defence response by the symbiotic alga } \\
\text { in response to oxidative stress }\end{array}$ \\
\hline Hsp 60 and 70 & $\begin{array}{l}\text { Function as outlined above but any in- } \\
\text { creases in concentration indicating a } \\
\text { defence response by the symbiotic alga } \\
\text { in response to stress }\end{array}$ \\
\hline Chloroplast Hsp & $\begin{array}{l}\text { A small molecular weight protein which } \\
\text { protects photosynthetic processes during } \\
\text { heat stress, oxidative stress and during } \\
\text { high irradiance. In most cases, these } \\
\text { proteins are only elicited by stressful } \\
\text { conditions }\end{array}$ \\
\hline
\end{tabular}

ternary pump (P 4000), autosampler (AS 3000 equipped with cooled sample tray, column oven and sample preparation capability) and photo diode array detector (UV 6000). System control, data collection and integration were performed using Chromquest software.

Aliquots of the clarified extract were loaded into the autosampler and maintained at $2{ }^{\circ} \mathrm{C}$ before being vortex-mixed with $1 \mathrm{M}$ ammonium acetate buffer $(1: 1 \mathrm{v} / \mathrm{v})$. Buffered extracts were injected $(100 \mu \mathrm{l})$ onto a Hypersil ${ }^{\circledR}$ MOS2 C-8 column (3 $\mu$ m particle size, $100 \times 4.6 \mathrm{~mm}$ ) maintained at $30^{\circ} \mathrm{C}$. Pigments were separated using a binary mobile phase system (70/30 [v/v] methanol/1.0 M ammonium acetate:100\% methanol). Flow rate was constant at $0.85 \mathrm{ml} \mathrm{min}^{-1}$.

Pigment identity was secured through co-elution with authentic pigments obtained from either Sigma Chemical or from VKI, Denmark. Confirmation of ana- lyte identity was achieved through spectral comparison to standards using the Chromquest software. Quantification of pigments was carried out at $444 \mathrm{~nm}$.

Measurement of algal densities. On collection, the diameters of baseline and experimental cores were measured with vernier calipers before fixation. Each core was fixed in $10 \%$ formalin $(24 \mathrm{~h})$, decalcified in $5 \%$ formic acid/formalin solution (48 h) and homogenised in $2 \%$ formalin using a tissue tearer (Ultra Turrax T25 at $13500 \mathrm{rpm})$. Zooxanthellae from 3 subsamples from each core were counted microscopically on Neubauer haemocytometer slides and counts normalised to coral surface area.

Chl a fluorescence. The photophysiology of coral symbiotic algae was investigated in coral cores from ambient and elevated seawater tanks using a pulse amplitude fluorescence system (MINIPAM/B, Walz) fitted with a blue light emitting diode (LED) range 440-505 nm, peak at $477 \mathrm{~nm}$. In this version of the instrument, the cut-off wavelength of the detector filter is $650 \mathrm{~nm}$ which allows detection from the main chl a emission at $685 \mathrm{~nm}$. As a result higher values of variable fluorescence might be expected compared with those using the more commonly fitted red LED instrument.

During darkness, well before dawn, initial fluorescence $\left(F_{\mathrm{o}}\right)$, maximal fluorescence $\left(F_{\mathrm{m}}\right)$ and the photochemical efficiency $\left(F_{\mathrm{v}} / F_{\mathrm{m}}\right)$ of Photosystem II (PS II) were recorded. These measurements were followed by records of steady state chl a fluorescence $\left(F_{\mathrm{t}}\right)$, maximal fluorescence $\left(F_{\mathrm{m}^{\prime}}\right)$ and effective quantum yield $\left(\Delta F / F_{\mathrm{m}^{\prime}}\right)$ for the rest of the day. All measurements were carried out in situ on experimental cores using a standard $5.5 \mathrm{~mm}$ diameter fibreoptic positioned $8 \mathrm{~mm}$ from the coral surface at an angle of $60^{\circ}$ by means of a specially constructed mount. Particular care was taken to avoid any shading of the sample during measurement.

Location of fluorescent pigments in the coral host. An additional 2 pairs of cores from the east and west faces of 2 coral colonies were sampled during the field collection, prior to the beginning of the experiment. These cores were used for the location of fluorescent pigments. Cores were anaesthetised for $30 \mathrm{~min}$ in a 1:1 solution of $0.36 \mathrm{M} \mathrm{MgCl}_{2}$ and seawater before fixation in $4 \% \rho$-formaldehyde solution. On return to the UK, pieces of tissue were removed from the skeleton using fine forceps, mounted on well slides and examined using confocal laser scanning microscopy (CLSM). A Bio-Rad MRC 600 confocal laser microscope, equipped with a $15 \mathrm{~mW}$ krypton-argon mixed gas laser giving an excitation line at $488 \mathrm{~nm}$, was used in this study. Excitation of specimens at $488 \mathrm{~nm}$ allowed imaging of fluorescent granules and chromatophores by their emissions at $520 \mathrm{~nm}$, while symbiotic algae were imaged by the red autofluorescence of their chloroplasts and 
emission at wavelengths longer than $585 \mathrm{~nm}$, following the procedure of Salih et al. (1998).

Statistical analyses. For assessing changes over time in molecular assays and algal pigment analyses, ANOVA followed by Tukey multiple comparisons were used. In some cases, data was log-transformed. In a limited number of cases, non-parametric Kruskal Wallis and Dunn's post hoc comparisons were required. For comparison of xanthophyll parameters between Days 1 and 2, data sets from each day were pooled. This was because no significant differences were found between categories and unpaired $t$-tests or Mann-Whitney tests carried out, depending on whether the data were homoscedastic or heteroscedastic, respectively. Standard ANOVA and Tukey multiple comparisons testing was used for evaluation of chl a fluorescence measurements at the beginning of the experiment but for comparisons of $F_{\mathrm{v}} / F_{\mathrm{m}}$ over the course of the experiment, repeated measures ANOVA was employed followed by Tukey multiple comparisons tests. In all comparisons, $\alpha$ values were maintained at 0.05 .

Paired $t$-tests were used for comparison of algal densities in baseline samples and in those collected at the end of the experiment. They were also used to compare molecular assays and pigment levels between east and west sides in baseline and experimental samples on Days 1 and 2 of the ambient and temperature treatments.

\section{RESULTS}

\section{Molecular assays}

The results of analysis of molecular biomarkers are summarised in Fig. 1 (ambient treatment) and Fig. 2
Fig. 1. Molecular marker concentrations (pg $\mu^{-1}$ soluble protein; except ubiquitin and CuZnSOD [Host] ng $\mu^{-1}$ soluble protein) for baseline (Day 0) and subsequent days in the ambient temperature experiment. Means \pm 1 SE. Open bars represent west sides of colonies, shaded bars east sides. * Above histograms indicates significant differences between east and west cores, while * and bars below each figure refer to significant differences over time. Significant differences: ${ }^{*}<0.05$,

$$
* *<0.01,{ }^{* * *}<0.001
$$
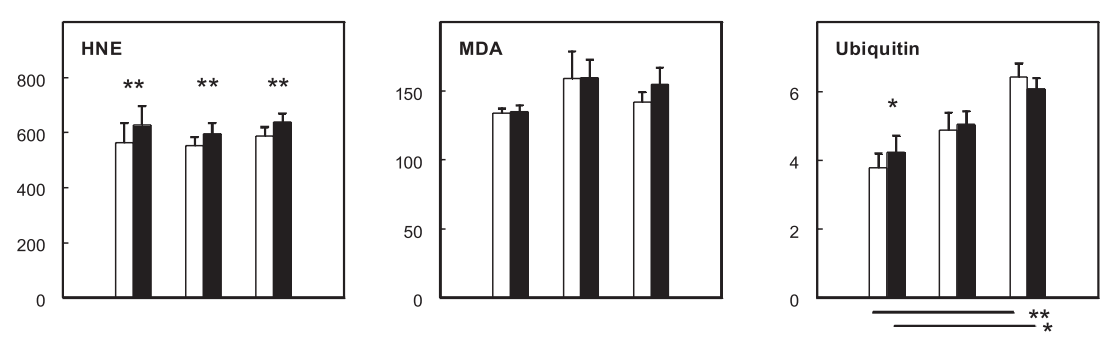

Day 0 Day 1 Day 2
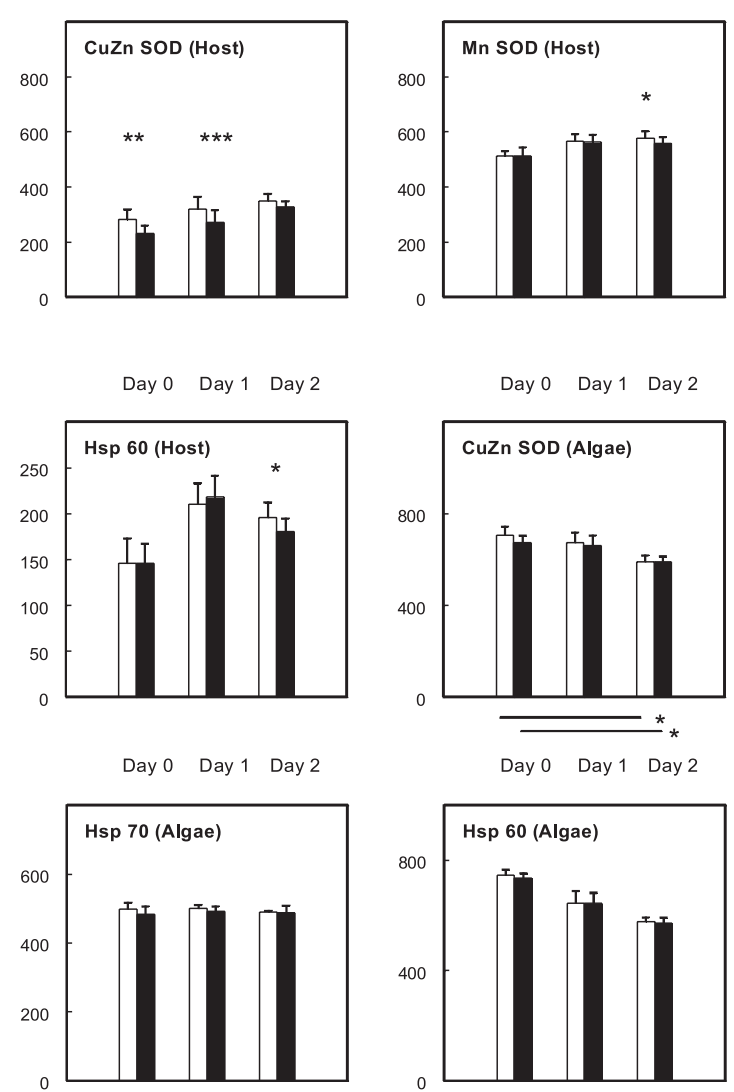

Day 0 Day 1 Day 2

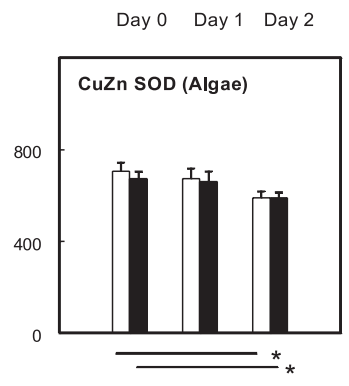

Day 0 Day 1 Day 2

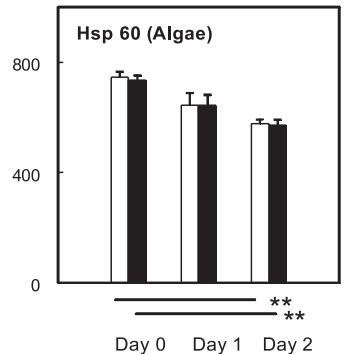

Day 0 Day 1 Day 2

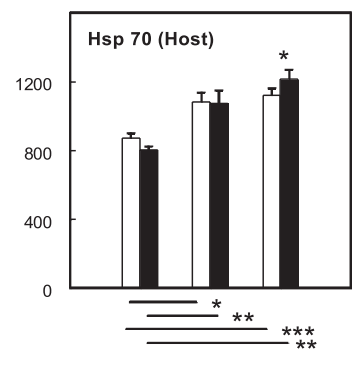

Day 0 Day 1 Day 2

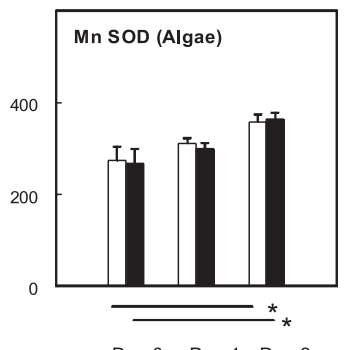

Day 0 Day 1 Day 2

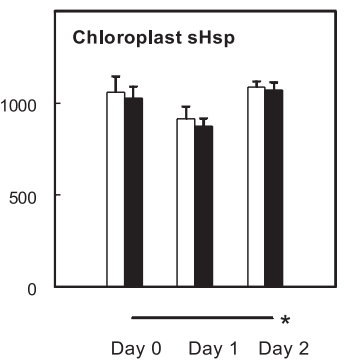




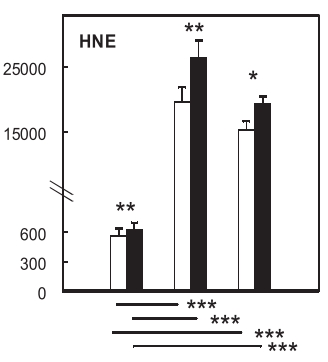

Day 0 Day 1 Day 2
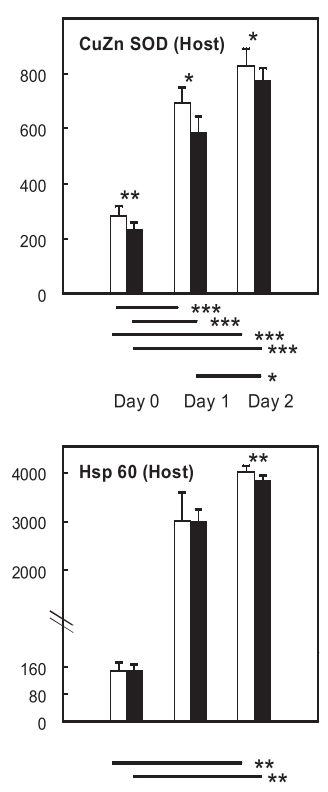

Day 0 Day 1 Day 2

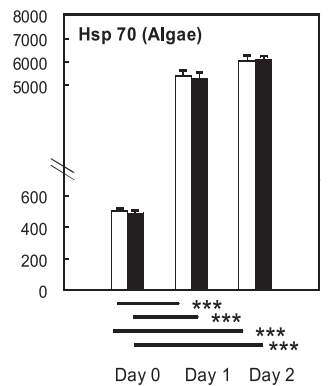

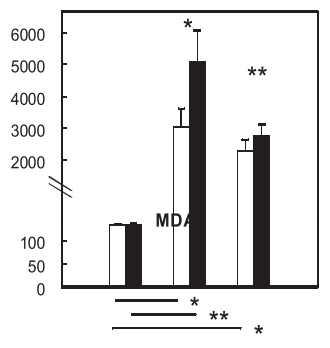

Day 0 Day 1 Day 2

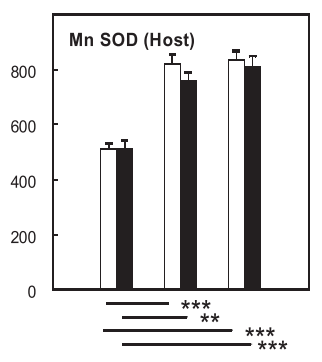

Day 0 Day 1 Day 2

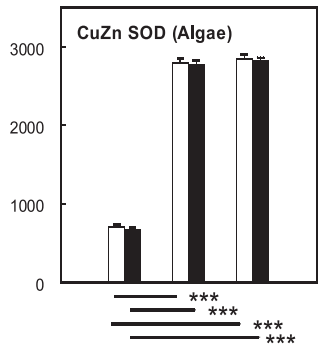

Day 0 Day 1 Day 2

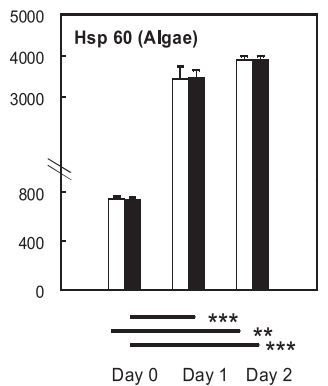

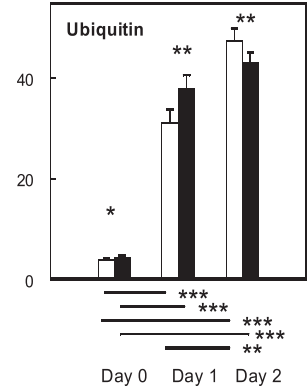
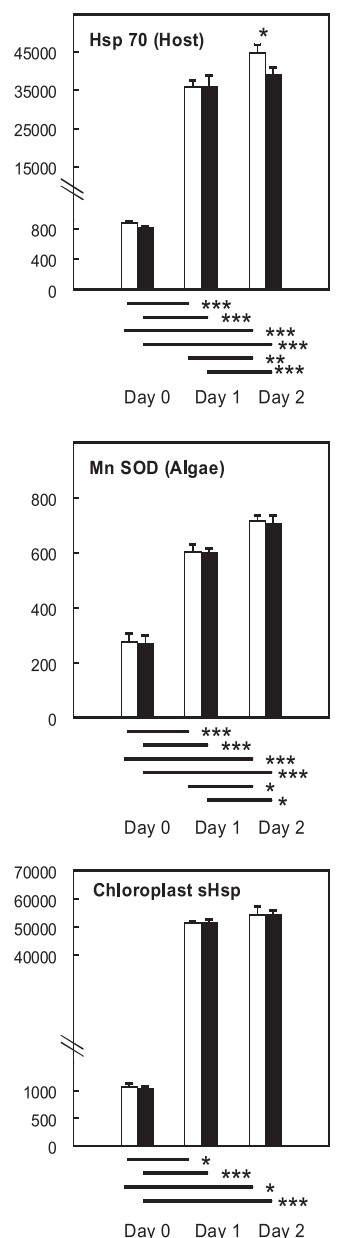

Fig. 2. Molecular marker concentrations as Fig. 1, but for elevated temperature experiment. Note axis breaks and scale changes on some plots

(elevated treatment), which also show the outcome of statistical analyses. In baseline cores, there were few differences in molecular biomarker concentrations between east and west apart from the indicators of oxidative stress (HNE) and protein damage (ubiquitin) as well as the coral host antioxidant-enzyme CuZnSOD (Fig. 1). Concentrations of HNE and ubiquitin in baseline cores were higher in east than in west cores, while coral host CuZnSOD levels were highest in west cores.
At ambient temperatures, there were higher concentrations of HNE in east cores on Days 1 and 2 of the experiment compared to west. Most host defences were higher in west cores on Day 1 (CuZnSOD) and Day 2 (MnSOD, Hsp60) than in east but on Day 2, Hsp70 levels were higher in east cores when compared to west. Both ubiquitin and host Hsp70 concentrations slightly increased in all cores, regardless of location, during the experiment. The algal antioxidative enzyme MnSOD also showed a small increase over the $2 \mathrm{~d}$ experiment although other algal biomarkers (CuZnSOD and Hsp60 in both east and west cores, and chlsHsp in east cores only) decreased over time.

In contrast to ambient temperatures, exposure to elevated sea temperature caused a significant and marked increase in all biomarkers of host and algal tissues both in east and west cores (Fig. 2). Measures of oxidative damage, protein damage and concentrations of host stress proteins increased 10- to 50-fold compared to baseline values. All measures of oxidative stress (HNE, MDA) and protein damage (ubiquitin) were higher in east sides compared to west (apart from ubiquitin on Day 2), while host defences (CuZnSOD, Hsp70, Hsp60) were higher in west cores than in east on either Days 1, 2 or both (Fig. 2). There were no differences between east and west sides of the coral in terms of algal biomarkers throughout the experiment at elevated temperature.

\section{Algal pigments}

In baseline samples, west cores showed higher concentrations of algal diatoxanthin $(p<0.004)$, and higher values for the algal xanthophyll ratio $\left(D_{t} / D_{d}+D_{t}\right)(p<0.002)$ and the total algal xanthophyll pool $(p<0.05)$ than east cores. There were, however, no differences in algal chl $a$, chlorophyll $c_{2}$, peridinin, diadinoxanthin or $\beta$-carotene concentrations between east and west sides of the coral.

For all measures, there were no significant differences between east and west cores at either ambient or elevated temperatures on Days 1 and 2. The only pigments which showed any changes over time in all cores, irrespective of original orientation, were algal diatoxanthin concentrations on Day 2 when xanthophyll cycling was limited by cloudy conditions (under- 
water PAR dose on Day $2=21.5 \mathrm{~mol} \mathrm{~m}^{-2}$ compared with $37.5 \mathrm{~mol} \mathrm{~m}^{-2}$ on Days 1 and 3). As a result of reduced irradiance on Day 2, both algal diatoxanthin concentrations and the xanthophyll ratio $D_{t} / D_{d}+D_{t}$ were reduced compared to values on Day $1(p<0.001)$.

\section{Algal densities}

Algal density data from all sampled cores are summarised in Fig. 3. At the beginning of the experiment (Day 0), east cores contained slightly fewer algae than west cores $(p<0.014)$. At the end of the experiment, as a result of exposure to ambient temperature, neither east nor west cores lost algae, while at the elevated temperature only east cores showed a reduction in algal density $(p<0.03)$. This reduction involved a $26 \%$ decline in algal numbers confirming the improved thermotolerance of western surfaces of coral colonies.

\section{Chl a fluorescence}

Fluorescence data obtained during the $4 \mathrm{~d}$ experiment showed marked diurnal fluctuations (Fig. 4) with a reduced depression in effective quantum yield $\left(\Delta F / F_{\mathrm{m}}{ }^{\prime}\right)$ on Day 2 in all cores, compared to Days 1 and 3 because of reduced irradiance on that day (as discussed above). East and west sides showed no significant differences in photochemical efficiency $\left(F_{\mathrm{v}} / F_{\mathrm{m}}\right)$ or $\Delta F / F_{\mathrm{m}}{ }^{\prime}$ in ambient or elevated temperature treatments at any sampling time.

Photochemical efficiency of the algae revealed no significant decline in $F_{\mathrm{v}} / F_{\mathrm{m}}$ over time at ambient temperature but there were significant fluctuations in $F_{\mathrm{v}} / F_{\mathrm{m}}$ from day to day in both east and west cores (Table 2) $(p<0.005)$. Post hoc statistical tests show that the differences for west cores were between Days 2 and 3, and 3 and 4, while those for east cores were between Days 1 and 2, 1 and 4, and 3 and 4. The high irradiance on Day 1 appears to have a damaging effect upon east but not west cores. On Day 2, the effect of overcast skies allowed an increase in $F_{\mathrm{v}} / F_{\mathrm{m}}$ in west cores but not in east. High irradiance on Day 3 caused chronic photodamage in both east and west cores.

At the elevated temperature, $F_{\mathrm{v}} / F_{\mathrm{m}}$ values declined over time $(p<0.001)$ in both east and west cores (Fig. 4) with differences being shown between Days 1 and 2, 1 and 3, 1 and 4, and 3

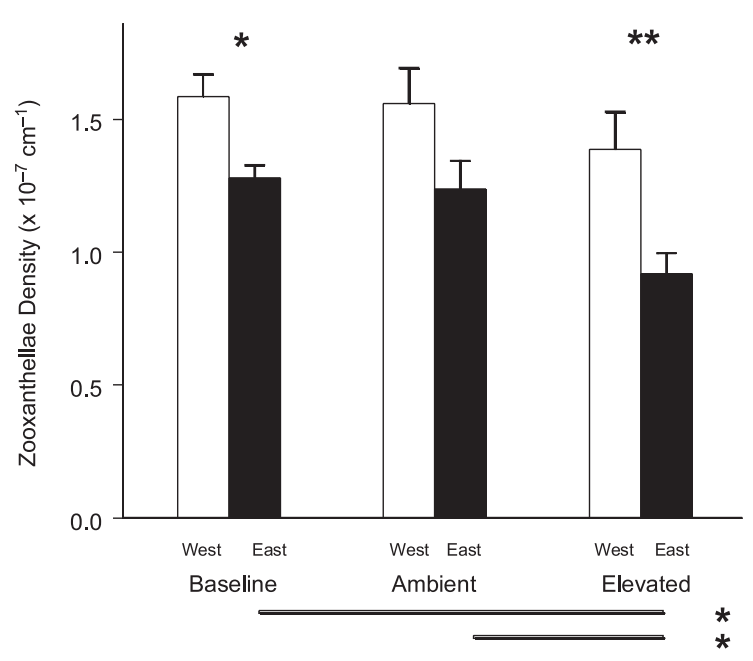

Fig. 3. Mean algal densities $( \pm 1 \mathrm{SE})$ of east and west cores in baseline (Day 0) and ambient and elevated temperature treatments (Day 3). Significant differences: ${ }^{*}<0.05,{ }^{* *}<0.01$

and 4. The effect of elevated temperature on chronic photoinhibition is clear in these results. The absence of a significant difference in $F_{\mathrm{v}} / F_{\mathrm{m}}$ between Days 2 and 3 is interesting because it reinforces the results from the ambient tank where the relatively dull conditions allowed an increase in $F_{\mathrm{v}} / F_{\mathrm{m}}$ in west cores. Both ambient and elevated temperature data underline the combined role that solar radiation and temperature have in inducing chronic photodamage.

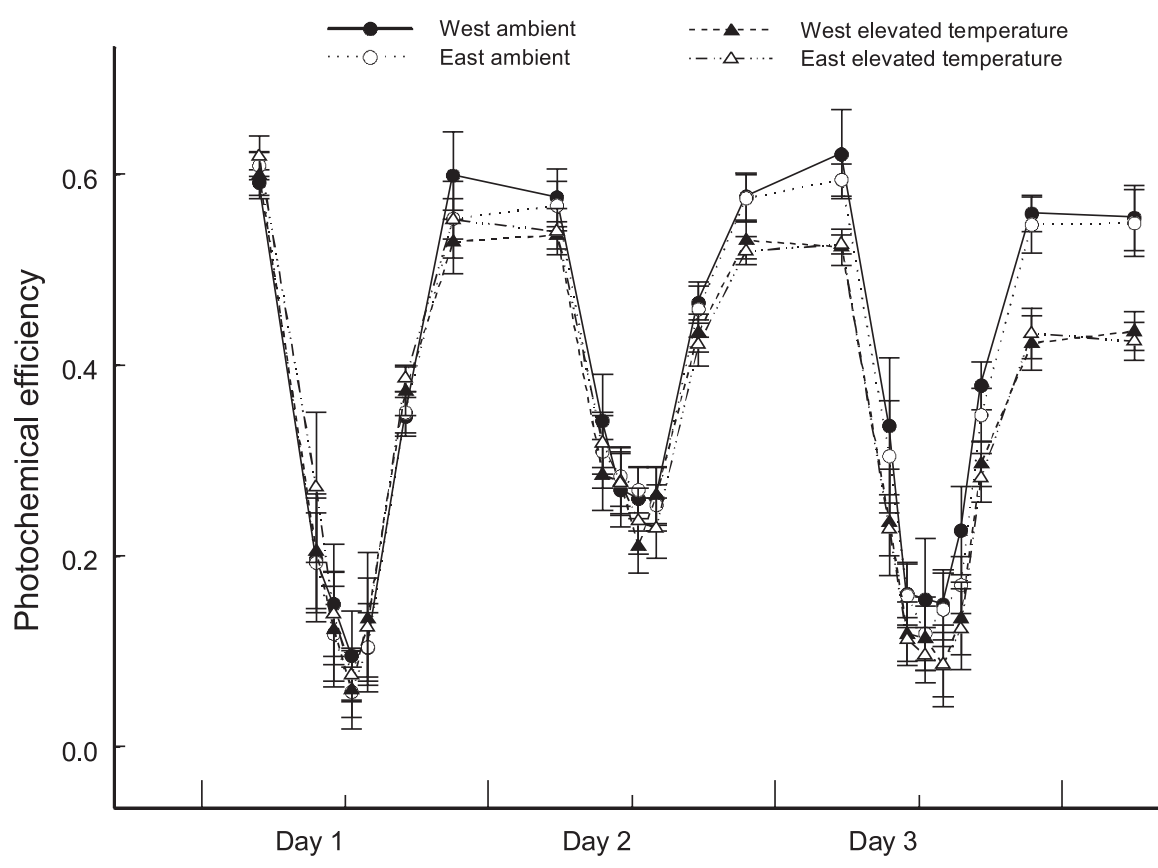

Fig. 4. Photochemical efficiency as measured by pulse amplitude fluorometry (PAM) for cores from Goniastrea aspera colonies over the time period of the experiment. Mean $\pm 1 \mathrm{SD}, \mathrm{n}=12$ 
Table 2. Tukey multicomparison statistics for $F_{\mathrm{v}} / F_{\mathrm{m}}$ measurements in east and west cores in ambient and elevated sea temperatures, and direction of change (shown by arrow). (A) West cores at ambient temperature; (B) east cores at ambient temperature; (C) east and west cores at elevated temperature. $\mathrm{ns}=$ not significant

\begin{tabular}{|c|c|c|c|c|}
\hline Time & Day 1 & Day 2 & Day 3 & Day 4 \\
\hline $\begin{array}{r}\text { (A) Day } 1 \\
\text { Day } 2 \\
\text { Day } 3 \\
\text { Day } 4\end{array}$ & & ns & $\begin{array}{c}\mathrm{ns} \\
\text { 仓 } \mathrm{p}<0.05\end{array}$ & $\begin{array}{c}\mathrm{ns} \\
\mathrm{ns} \\
\mathrm{p}<0.01\end{array}$ \\
\hline $\begin{array}{r}\text { (B) Day } 1 \\
\text { Day } 2 \\
\text { Day } 3 \\
\text { Day } 4\end{array}$ & & ת $\mathrm{p}<0.01$ & $\begin{array}{l}\mathrm{ns} \\
\mathrm{ns}\end{array}$ & $\begin{array}{c}\text { p }<0.001 \\
n s \\
\text { n }<0.01\end{array}$ \\
\hline $\begin{array}{r}\text { (C) Day } 1 \\
\text { Day } 2 \\
\text { Day } 3 \\
\text { Day } 4\end{array}$ & & $\mathrm{p}<0.001$ & $\begin{array}{c}\text { ת } \mathrm{p}<0.001 \\
\mathrm{~ns}\end{array}$ & $\begin{array}{c}\text { ת }<0.001 \\
n s \\
\text { ת } p<0.001\end{array}$ \\
\hline
\end{tabular}

\section{Fluorescent pigments}

Confocal imaging revealed abundant areas of fluorescent pigment in tissues extracted from west cores (Fig. 5) compared to those from the east where little fluorescence was visible, although these differences were not quantified. Interestingly, fluorescent pigments were most abundant in the endoderm of west cores. Pigments surrounded the symbiotic algae, with very little fluorescence evident in the ectoderm.

\section{DISCUSSION}

Our earlier work indicated within colony variability in coral bleaching susceptibility during a natural bleaching event, which we believed was due to the prior experience of west sides of colonies to high irradiance (Brown 1997). Subsequently, field and experimental observations showed that west facing surfaces of corals were more tolerant of both high temperatures and high irradiance than east surfaces which were shaded from high irradiance on afternoon spring tides (Brown et al. 2000a,b, 2002a). These differential tolerances have been substantiated in the present study and were reflected in the data in several different ways. Firstly, in the baseline samples where algal densities in east cores were slightly lower than those in the west, although in general, algal numbers in both sets of cores were high in February 2001 compared to previous years (Brown et al. 1999b). Secondly, in baseline molecular markers where 3 of the 12 assays revealed small differences between east and west cores. These differences were higher levels of oxidative stress
(HNE) and protein damage (ubiquitin) in east cores compared to west, and higher concentrations of the host antioxidant enzyme CuZnSOD in west cores. Thirdly, during the elevated temperature experiment when greater algal loss and higher levels of oxidative stress (HNE, MDA) and protein degradation (ubiquitin) were noted in east cores compared to those from the west. At the same time, west cores showed higher concentrations of defences in terms of CuZnSOD and the stress proteins (Hsp60, Hsp70). Fourthly, west cores demonstrated less chronic photoinhibition and greater PS II recovery potential than east cores when exposed to high irradiance at ambient temperature.

One of the key questions arising out of these results and those of earlier work (Brown et al. in press) relates to whether the observed thermotolerance was specific to the animal host, the symbiotic algae, or whether it was a feature of both host and algae. The present study has gone some way to answering this question. Although we have looked at only a limited number of molecular biomarkers, which represent but a small element of the total defensive capability of the coral symbiosis, there are strong indicators that the host plays a significant role in the improved thermal/irradiance tolerance of west sides of Goniastrea aspera through increased production of CuZnSOD, Hsp60 and Hsp70 under thermal stress. In addition, the high concentrations of fluorescent pigment present in host tissues will boost photoprotection, which in turn will reduce susceptibility of the coral to the damaging effects of light at elevated temperature.

Nonetheless, the defences of the symbiotic algae should not be discounted in the overall tolerances of the symbiotic unit, even though there were no differences in algal biomarkers between east and west cores during the experiment. Chl a fluorescence measurements in the present experiments indicate that algae from both east and west sides of the colony are extremely resilient to environmental stress with a marked capacity for recovery from dynamic photoinhibition at midday. In addition, both host and algal tissues in all cores showed a marked increase in antioxidant enzyme and stress protein production (including algal ChlsHsp) at elevated temperature, irrespective of core orientation. While the induction of stress proteins in corals exposed to high temperatures has already been amply demonstrated (Black et al. 1995, Hayes \& King 1995, Fang et al. 1997, Sharp et al. 1997, Gates \& Edmunds 1999, Downs et al. 2000), previously there has been no distinction between Hsp production in the coral host and that in symbiotic algae. In the present study, both host and algae showed spectacular increases in Hsp60 and Hsp70 so that by Day 2 approximately $5 \%$ of total soluble protein production could be accounted for by these 2 stress proteins alone. 


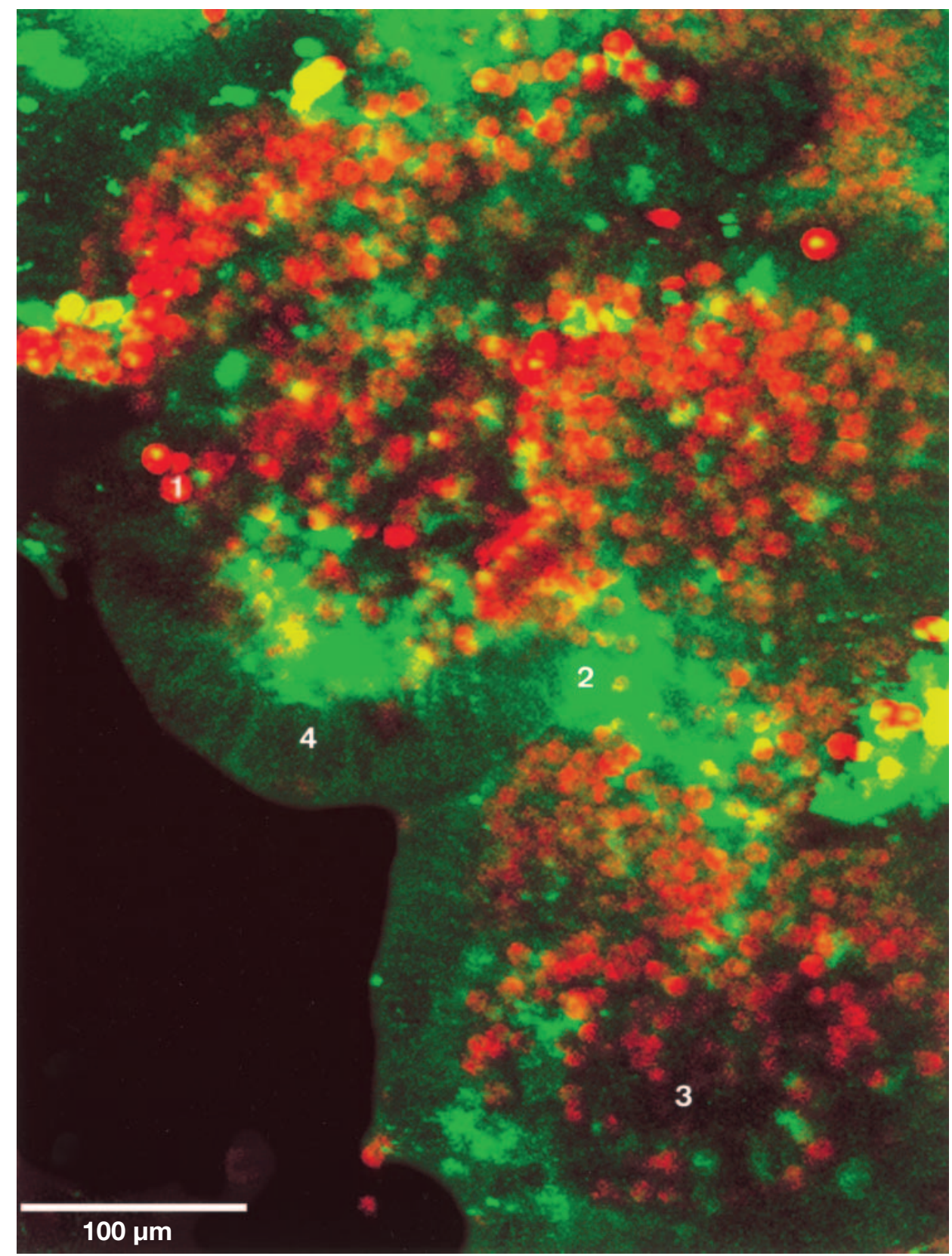

Fig. 5. Goniastrea aspera. Confocal microscope image of oral tissues from west core. $1=$ zooxanthellae, $2=$ fluorescent pigment, $3=$ endoderm, 4 = ectoderm

The xanthophyll cycle and the xanthophyll pigments themselves also ameliorate the damaging effects of light at elevated temperatures in higher plants (Demmig-Adams \& Adams 1993, Havaux et al. 2000). Additionally, it is likely that they have a similar role in corals (Ambarsari et al. 1997, Brown et al. 1999b) with artificial inhibition of xanthophyll cycling in corals leading to severe oxidative stress (Brown et al. 2002b). In the present study, no differences were noted in xanthophyll pigments and xanthophyll parameters between east and west sides of corals at elevated or ambient temperatures. However, baseline west cores did show a higher xanthophyll pool than east cores, probably in response to the higher irradiance received by the western surfaces of colonies in their natural setting. A similar finding for west cores was also noted by Ambarsari (1998) during the dry season, when west surfaces of corals receive maximal irradiance. In the 
present study, baseline west cores also showed higher xanthophyll ratios than east cores, again as a result of exposure to higher irradiance on western surfaces at time of collection (Brown et al. 1999b, 2000b). What is notable from the experimental data set is how rapidly algae from the east sides of corals acclimatised to high irradiance in experimental aquaria with respect to their xanthophyll cycling capability, a result which is supported by earlier work (Brown et al. 1999b, 2000b). Overall, it would appear that while key photoprotective mechanisms, such as the xanthophyll cycle, allow symbiotic algae from east cores to quickly acclimatise (within hours) to the experimental conditions in the present study, stress defences in the coral host do not.

Finally, it is interesting to consider why tolerance to irradiance stress might confer co-tolerance to elevated temperature in a shallow water coral such as Goniastrea aspera. The fact that photoprotection is a significant defence against elevated temperature has been reported in several studies (Warner et al. 1996, Brown 1997, Brown et al. 2000a, Hoegh-Guldberg 1999), which highlight that a critical problem for corals at elevated temperatures is the resultant increased susceptibility to damage by high irradiance. Any defence mechanism which limits the penetration of light into coral tissues (e.g. fluorescent pigments) or which dissipates excess light harmlessly (e.g. the xanthophyll cycle) will obviously reduce potential damage to the symbiosis. Any additional defences (e.g. antioxidant enzymes) which inactivate harmful oxygen radicals will also help mitigate against tissue breakdown. It is interesting to note that in the present study, another defensive mechanism (host Hsp70) increased on exposure of all cores to high irradiance at ambient temperature. Many of the heat-shock proteins respond not only to temperature but also to a variety of stresses that include irradiance (Feder \& Hoffman 1999, Heckathorn et al. 1999). It is therefore not surprising that the more highly irradiance-stressed west sides of G. aspera show a greater magnitude of protein expression than east sides and that this expression, specifically in host tissues, will go some way to conferring greater tolerance to elevated temperature.

The present study is noteworthy, not only because it highlights that acclimatisation to high irradiance may be significant in improving thermotolerance of corals in the short term, but also because it demonstrates the importance of host tissues in the maintenance of the intact coral symbiosis of west surfaces of Goniastrea aspera under stress. Future questions should address the physiological plasticity of gene expression of defensive proteins such as Hsps and antioxidant enzymes. Only then will we be in a better position to understand organismal-level adjustment to thermotolerance and species-level differences in responses to environmental temperature changes.
Acknowledgements. We thank the Director and staff of the Phuket Marine Biological Center for their support, particularly Dr. Hansa Chansang, Sombat Poovachiranan, Niphon Phongsuwan, Ukkrit Satapoomin and Dr. Somkiat Khokiattiwong. We also thank Jessica Ruston and Charles Robinson of EnVirtue Biotechnologies Inc, USA, for assistance in molecular analyses; John Fauth for initial statistical analyses and Trevor Booth of the University of Newcastle upon Tyne for help with confocal microscopy. We also thank Prof. O. Hoegh-Guldberg and 3 anonymous referees for their helpful comments on the manuscript. Finally, we are grateful to the Natural Environment Research Council, UK, and EnVirtue Biotechnologies, USA, for financial support of this work.

\section{LITERATURE CITED}

Ambarsari I (1998) The nature and significance of pigments in the symbiotic algae of corals. PhD thesis, University of Newcastle upon Tyne, Newcastle

Ambarsari I, Brown BE, Barlow RG, Britton G, Cummings D (1997) Fluctuations in algal chlorophyll and carotenoid pigments during solar bleaching in the coral Goniastrea aspera at Phuket, Thailand. Mar Ecol Prog Ser 159: 303-307

Baker A (2001) Reef corals bleach to survive change. Nature 411:765-766

Barlow RG, Cummings DG, Gibb SW (1997) Improved resolution of mono- and divinyl chlorophylls $a$ and $b$ and zeanthin and lutein in phytoplankton extracts using reverse phase C-8 HPLC. Mar Ecol Prog Ser 161:303-307

Berkelmans R, Willis BL (1999) Seasonal and local spatial patterns in the upper thermal limits of corals on the inshore Central Great Barrier Reef. Coral Reefs 18:219-228

Black NA, Voellmy R, Szmant AM (1995) Heat shock protein induction in Montastrea faveolata and Aiptasia pallida exposed to elevated temperature. Biol Bull 188:234-240

Brown BE (1997) Coral bleaching: causes and consequences. Coral Reefs 16:S129-S138

Brown BE, Dunne RP, Scoffin TP, Le Tissier MDA (1994) Solar damage in intertidal corals. Mar Ecol Prog Ser 105: 219-230

Brown BE, Ambarsari I, Warner ME, Fitt WK, Dunne RP, Gibb SW, Cummings DG (1999a) Diurnal changes in photochemical efficiency and xanthophyll concentrations in shallow water reef corals: evidence for photoinhibition and photoprotection. Coral Reefs 18:99-105

Brown BE, Dunne RP, Ambarsari I, Le Tissier MDA, Satapoomin U (1999b) Seasonal fluctuations in environmental factors and variations in symbiotic algae and chlorophyll pigments in four Indo-Pacific coral species. Mar Ecol Prog Ser 191:53-69

Brown BE, Dunne RP, Goodson MS, Douglas AE (2000a) Bleaching patterns in reef corals. Nature 404:142-143

Brown BE, Dunne RP, Warner ME, Ambarsari I, Fitt WK, Gibb SW, Cummings DG (2000b) Damage and recovery of photosystem II during a manipulative field experiment on solar bleaching in the coral Goniastrea aspera. Mar Ecol Prog Ser 195:114-124

Brown BE, Dunne RP, Goodson MS, Douglas AE (2002a) Experience shapes the susceptibility of a reef coral to bleaching. Coral Reefs 21:119-126

Brown BE, Downs CA, Dunne RP, Gibb SW (2002b) Preliminary evidence for tissue retraction as a factor in photoprotection of corals incapable of xanthophyll cycling. J Exp Mar Biol Ecol 277:129-144 
Buddemeier RW, Fautin DG (1993) Coral bleaching as an 'adaptive' mechanism. BioScience 42:320-326

Buddemeier RW, Smith SV (1999) Coral adaptation and acclimatization: a most ingenuous paradox. Am Zool 39: $1-9$

Coles SL, Jokiel PL (1978) Synergistic effects of temperature, salinity and light on the hermatypic coral Montipora verrucosa. Mar Biol 49:187-195

Coles SL, Jokiel PL, Lewis CR (1976) Thermal tolerance in tropical versus subtropical Pacific reef corals. Pacif Sci 30:159-166

Craig P, Birkeland C, Belliveau S (2001) High temperatures tolerated by a diverse assemblage of shallow water corals in America Samoa. Coral Reefs 20:185-189

Demmig-Adams B, Adams WW (1993) The xanthophyll cycle. In: Young A, Britton G (eds) Carotenoids in photosynthesis. Chapman and Hall, London, p 206-251

Dove SG, Hoegh-Guldberg O, Ranganathan S (2001) Major colour patterns of reef building corals are due to a family of GFP-like proteins. Coral Reefs 19:197-204

Downs CA, Mueller E, Phillips S, Fauth JE, Woodley CM (2000) A molecular biomarker system for assessing the health of coral (Montastraea faveolata) during heat stress. Mar Biotechnol 2:533-544

Fang LS, Huang SP, Lin KLN (1997) High temperature induces the synthesis of heat-shock proteins and the elevation of intracellular calcium in the coral Acropora grandis. Coral Reefs 16:127-131

Feder ME, Hoffman GE (1999) Heat-shock proteins, molecular chaperones, and the stress response: evolutionary and ecological physiology. Annu Rev Phys 61:243-282

Fitt WK, Brown BE, Warner ME, Dunne RP (2001) Coral bleaching: interpretation of thermal tolerance limits and thermal thresholds in tropical corals. Coral Reefs 20:51-65

Gardiner JS (1903) The fauna and geography of the Maldive and Laccadive Archipelagoes. Cambridge University Press, Cambridge

Gates RD, Edmunds PJ (1999) The physiological mechanisms of acclimatization in tropical reef corals. Am Zool 39:30-43

Ghosh S, Gepstein S, Heikkila JJ, Dumbroff BG (1988) Use of a scanning densitometer or an ELISA plate reader for measurement of nanogram amounts of protein in crude extracts from biological tissue. Anal Biochem 169:227-233

Havaux M, Bonfils JP, Lutz C, Niyogi KK (2000) Photodamage of the photosynthetic apparatus and its dependence on the leaf developmental stage in the npq1 Arabidopsis mutant deficient in the xanthophyll enzyme violaxanthin de-epoxidase. Plant Physiol 124:273-284

Hayes RL, King CM (1995) Induction of 70-kD heat shock protein in scleractinian corals by elevated temperature: significance for coral bleaching. Mol Mar Biol Biotechnol 4:36-42

Heckathorn SA, Downs CA, Coleman JS (1999) Small heat

Editorial responsibility: Otto Kinne (Editor),

Oldendorf/Luhe, Germany shock proteins protect electron transport in chloroplasts and mitochondria during stress. Am Zool 39:865-876

Hoegh-Guldberg O (1999) Climate change, coral bleaching and the future of the world's coral reefs. Mar Freshw Res 50:839-866

Hoegh-Guldberg O, Jones R (1999) Diurnal patterns of photoinhibition and photoprotection. Mar Ecol Prog Ser 183: 73-86

Hoegh-Guldberg O, Jones RJ, Ward S, Loh WK (2002) Is coral bleaching really adaptive? Nature 415:601-602

Lesser MP (1997) Oxidative stress causes coral bleaching during exposure to elevated temperatures. Coral Reefs 16: 187-192

Lesser MP, Shick JM (1989) Photoadaptation and defences against oxygen toxicity in zooxanthellae from natural populations of symbiotic cnidarians. J Exp Mar Biol Ecol 134: 129-141

Lesser MP, Stochaj, Tapley WR, Shick JM (1990) Bleaching in coral reef anthozoans: effects of irradiance, ultraviolet radiation and temperature on the activities of protective enzymes against active oxygen. Coral Reefs 8:225-232

Le Tissier MDA, Brown BE (1996) Dynamics of solar bleaching in the intertidal reef coral Goniastrea aspera at Ko Phuket, Thailand. Mar Ecol Prog Ser 169:113-121

Orr AP, Moorhouse FW (1933) Variations in physical and chemical conditions. Scientific Reports Great Barrier Reef Expedition 2:87-98

Rowan R, Knowlton N, Baker A, Jara J (1997) Landscape ecology of algal symbionts creates variation in episodes of bleaching. Nature 388:265-269

Salih A, Hoegh-Guldberg O, Cox G (1998) Photoprotection of symbiotic dinoflagellates by fluorescent pigments in reef corals. In: Greenwood JG, Hall NJ (eds) Proc Aust Coral Reef Soc 75th Anniversary Conference. University of Queensland, Brisbane

Salih A, Larkum A, Cox G, Kuhl M, Hoegh-Guldberg O (2000) Fluorescent pigments in corals are photoprotective. Nature 408:850-853

Sharp VA, Brown BE, Miller D (1997) Heat shock protein (hsp70) expression in the tropical reef coral Goniopora djiboutiensis. J Therm Biol 22:11-19

Shick JM, Lesser MP, Jokiel PL (1996) Effects of ultraviolet radiation on corals and other organisms. Global Change Biol 2:527-545

Tomascik T, Mah AJ, Nontji A, Moosa MK (1997) The ecology of the Indonesian seas, Part 1. Periplus Additions, Hong Kong

Ware JW (1997) The effect of global warming on coral reefs: acclimate or die. Proc 8th Int Coral Reef Symp 1:527-532

Warner ME, Fitt WK, Schmidt GW (1996) The effects of elevated temperature on the photosynthetic efficiency of zooxanthellae in hospite from four different species of reef coral: a novel approach. Plant Cell Environ 19:291-299

Submitted: March 3, 2002; Accepted: July 18, 2002

Proofs received from author(s): October 14, 2002 